\title{
Change of Editorship 2012
}

It is our pleasure to welcome Dr. Jean-Claude Manuguerra of the Institut Pasteur in Paris as the new Editor-inChief of Intervirology. An experienced virologist, Dr. Manuguerra is head of the CIBU Laboratory for urgent response to biological threats in France and beyond. Currently, he also serves as president of the French Pandemic Planning Committee, a role which made him known to the general public as this group prepared the contingency plans for viral pandemics such as SARS and the avian or swine flu. We are certain that his vision, drive and enthusiasm will ensure Intervirology's continued growth and success, and look forward to a pleasurable and fruitful collaboration with Dr. Manuguerra.

First published in 1973, founding Editor J.L. Melnick, Intervirology's aim has been to provide a forum for the international virology community. The journal concentrated on new developments in human and animal virology, focusing on viral pathogenesis, immunology, diagnosis, prophylactics and therapy. Themed issues, devoted to overviews of specific topics or viral diseases and edited by guest editors, were published regularly.

In 2004, Prof. Dr. U.G. Liebert, Leipzig, took over the stewardship of the journal. Guiding the Intervirology team for the next 9 years, Prof. Liebert continued to build the journal's reputation, which attracts renowned contributors from around the world. The impact factor 2011 with 2.337 is the highest impact factor the journal had in the last 10 years and today Intervirology continues to cover successfully all of basic and clinical virology, including prophylaxis, epidemiology as well as vaccine development and therapy of viral diseases.

Thanking Prof. Liebert for his efforts and commitment, we wish him continued success for his many professional as well as personal endeavors and activities.
Let me seize this Publisher's Note with a more general view on academic publishing and the added value that we as the publisher fulfill. It is in the interests of both authors and readers that published content is of the highest quality. Karger Publishers reviews all submitted papers in close cooperation with renowned researchers and scientists for their scientific value, topicality and importance (peer review system). Accepted manuscripts are then carefully copy edited and formatted, images and tables are enhanced, and thus the papers become clear and easy-to-read and are presented in an attractive design. Digitalized, fully citable and published online and in print, they are then ready for dissemination via bibliographic services, databases and online search engines. Now the articles are continually at the disposal of libraries and their users, researchers and clinicians worldwide.

Concerning the 'open access' discussion, like all businesses, the service our publishing house provides to the scientific community deserves acknowledgement as well as the rewards that follow. We want to be able to uphold our contribution to communication within the scientific community.

To keep the cycle of knowledge and information moving for the good of us all, a close network of many professionals is of the utmost importance. Looking forward to continuing our successful cooperation, we would like to take this opportunity to thank the Editors and Editorial Board members, reviewers, authors and readers of Intervirology for the confidence they have in us and for their continued collaboration.

The Publishers

\section{KARGER}

ㄷ 2012 S. Karger AG, Basel

Fax +41613061234

E-Mail karger@karger.ch

www.karger.com 